\title{
Perspectives about the difference in the relevance of American and European Political Science
}

\author{
Bo Rothstein
}

Blavatnik School of Government and Nuffield College, Oxford University

\section{Introduction}

Issues about the relevance of political science have recently been raised, both within the discipline, and from the world outside academia (Stoker, Peters, and Pierre 2015, Kristof 2014). To some extent, this discussion has been triggered by the attack from the Republican Party in the US Congress against funding for Political Science by the National Science Foundation. One of the arguments put forward for cutting funding for Political Science is that, unlike cancer research, advancement of our knowledge of how the political system works cannot save lives. Seen from a European perspective, a puzzling feature of this debate is why our esteemed American colleagues have not been able to successfully counter this attack which has been directed, not only at funding, but at the very external legitimacy of the discipline. Why have there not been more effective arguments showing that the discipline has a huge relevance, not least when it comes to matters of life and death (Holmberg and Rothstein, 2012)? After all, American political science is not just part of the global discipline of political science; it dominates that discipline - in terms of prestige, number of leading scholars, highly ranked journals and renowned university departments, etc.

In this essay I will discuss this from my position as a political scientist from one of the Nordic countries. My views below are not built on any systematic collection of data but solely on some personal observations and experiences. My argument in short is that there are four overlooked but potentially important institutional differences between American and European political science that may have implications for the issue of relevance understood as the contributions the discipline can offer the public debate about public policy. They are; the relation to education in law, the relation to public administration, the relation between political theory/philosophy and empirical research within the discipline and, lastly, the institutionalization of intellectual exchange. 


\section{The drain to law schools}

During the spring semester in 2006, I was invited to serve as Visiting Professor at Harvard University, which included teaching a class of upper-level undergraduates. My course was titled 'Corruption, Social Trust and Human Well-Being in a Comparative Perspective'. I had never taught outside the Scandinavian countries before so this was a new experience to me, not least the 'shopping week' when students went to different introductory lectures and then decided which courses to take - a practice that I had no experience of, but found quite compatible with how I perceived the consumerist ideology in the United States. Eventually, I ended up with 18 students, most of them seniors. I enjoyed teaching this class immensely. The students were (of course) very smart and eloquent but also very engaged in the course. My plan for lecturing soon fell apart and the class turned itself into a full-fledged seminar in which the students really spoke their mind and the discussions often continued in the cafeteria long after class had ended.

At the end of the course, the students invited me to an informal gathering and since they were mostly seniors I took the opportunity to ask how many of them were planning to take a Ph.D. in political science. As it turned out, I was in for one of my biggest surprises in my professional career. The students looked at me, most of them with a surprising look in their face, and I was told that such an idea was not at all what they had in mind for their future careers. Several of them then asked me why I had asked them such a strange question. Well, I said, this would be a very common thing for students like them in my part of the world to do. They were all very engaged in the topics of the course and had accepted my main message that corruption and others forms of dysfunctional government institutions had a detrimental effect on social trust and also for almost all measures of human well-being. For students like these in the Nordic countries, a career in political science (or some other social science) research would be both an obvious and quite attractive option, not least for getting a position from where one could influence policy. But no, none of the 15 or so seniors had thought about becoming a political scientist. And so, I asked them what they planned to do instead. The answer I got was that about half of them wanted to work for some international NGO or international organization that is in the business of 'saving the world'. The other half planned to apply to law school. Then my jaws dropped for the second time during that evening. Why law school? Knowing how engaged these students were in the policy issues we had discussed 
during the course, this was completely inexplicable to me. Of course, my first question was if this was because of the money they could earn practicing law in the US. But no, these students were not in it for the money. Instead, they explained to me that the really wanted to work in an area where they could influence policy on the issues we had been discussing during the course, and for this a law degree was the right thing. Again, I was completely surprised since law in the Nordic countries is a career you would go into if you do not want to influence policy or be seen as having a partisan or policy agenda. The law profession, with some minor exceptions, is thought of as a very technical, non-political and non-partisan business. There are very few people with law degrees in Parliaments in the Nordic countries and while judicial review formally exists, it is very little used by the courts. In general, judges in particular but also lawyers are seen, and want to be seen, as impartial, non-partisan judicial technocrats, not as policy advocates. If I would ask one hundred Swedish political scientists to name the President of the Swedish Supreme Court, my experience is that maybe one would know. However, quite a number of my colleagues would know who the name of the Chief Justice of the U.S. Supreme Court and they can often name a couple of the other Supreme Court judges.

This little story is meant to illustrate my first point about the difference between the relevance of political science in the United States and in most of Europe and especially in the Nordic countries. Namely that, comparatively speaking, American political science is losing a huge number of young talented people, who would likely use their future scholarly knowledge for policy relevant issues, to the law schools. In the Nordic countries, many of the same type of students that I had in this class would become political scientists and many of them would either be engaged in policy issues and or they would make sure that their research had policy relevance. Since my semester at Harvard, I have spoken to quite a number of colleagues at U.S. universities about this issue and my stark impression is that my experience was not unique. On the contrary this is a problem 'for real' in American political science. I can add that while I was very impressed by the undergraduate students at Harvard, I could not say the same about the majority of the graduate students. At the seminars I attended, many of them came across as quite 'nerdy' people that had honed in on some quite technical methodological specialty that was miles away from anything where one could find any policy relevance. My impression was also that many of them felt as if they had been forced to 'enlist' to a specific theoretical approach that they were not supposed to question. Six years later, when spending a 
semester at Stanford, I had very much the same experience when attending a graduate seminar in comparative politics.

What are the consequences of this drain of young talent with policy ambitions? My impression is that an argument often heard from colleagues at U.S. universities, but not so much from colleagues in Europe, is that 'I am doing basic, not applied, research'. This is an argument I have come to think of as maybe having some relevance in natural science, but not so much in social science. One argument for this relates to the three Nobel Laureates that are closest to (or in one case within) the political science discipline, namely John Nash, Douglass C. North and Elinor Ostrom. All of them started out with quite applied questions. Nash - how to avoid a nuclear war between the super-powers? North, asking why some countries are so much richer than others? And Ostrom, why some local groups manage to establish institutions that preserve the natural resources they are dependent on, while others fail to do so? From what I know, Nash did not get the Nobel Prize for his empirical research but North and Ostrom did. While stellar scholars, 'methodological rigor' as it is now understood and taught at most graduate program at the leading U.S. universities, was not their main thing. Instead, they started out from real world and very 'applied' problems, used a variety of methodological approaches and were not intellectually enslaved by some theoretical approach they had been enlisted to as Ph.D. students.

\section{The Iron Wall I: Political Science and Public Administration in America}

In addition to the 'drain to law schools', my impression is that for the relevance question, the U.S. differs from Europe in general and from the Nordic countries in particular in two other respects. These are what I would call the two 'iron walls' in American political science. One of these is between empirical political science and political theory, the other is between the discipline as a whole and public administration. In both cases, while there are marked separations in Europe as well, they are not that 'cast in stone' as seems to be the case in the U.S. Starting with public administration, in the Nordic countries this is at most universities an integrated subfield of the political science discipline and thus not a separate academic field with separate schools, academic careers and training. A case in point is the newly published Oxford Handbook of Swedish Politics that contains no less than ten chapters about the public administration in the country (Pierre, 2015). This is important for the obvious reason that, if we are interested in what the political system actually can do for improving people's life, this 
is usually done through a public administration lens. It is the public administration that directly or indirectly, provides (or does not succeed in providing) personal safety, the rule of law, economic security and civil liberties. In most countries, it is also the public administration that provides (and/or regulates the providers) of health care, basic education, social insurance and various forms of infrastructure. If the relevance of the discipline is related to the wellbeing of the people governed by the political system, excluding issues about how the public administration is organized and operates must have negative implications for how relevant the research can be. Just to take one example, most political scientists believe that political legitimacy is a central goal for a how a policy is organized. And most also believe that democratic rights are the central factor for establishing political legitimacy. Empirically, this turns out not to be the case. There are now four studies based on large comparative survey data showing that when people make up their mind whether or not they perceive their government is legitimate, issues related to the public administration such as the rule of law, control of corruption and government effectiveness are more important for them than are democratic rights (Gilley 2009; Gjefsen, 2012; Linde and Dahlberg 2016; Holmberg and Dahlberg 2015). The same effect can be seen for the support of social and welfare state policies. As shown by Svallfors (2013), a person in Europe with a leftist ideological orientation but who in the survey reports that he or she believes that the public administration of the system of taxation or public health care is incompetent or unfair, will state a preference for less public spending and lower taxes. However, the same type of person who in the survey states that these parts of the public administration are competent and act in a fair manner will also support higher public spending and state a willingness to pay higher taxes. While this point (to some extent) was made by Theda Skocpol (1992) in the 'Bringing the State In' approach launched in the mid-1980s, despite all its impressive achievements it failed to bring the public administration perspective into American political science.

Public administration issues seem to be particularly important for developing countries. In order to succeed in improving human wellbeing, it seems more important for developing countries to secure a high level of government quality (aka state capacity) than establishing electoral democracy (Rothstein, 2011; Fukuyama, 2014a). While the correlations between almost all standard measures of human well-being (infant mortality, percentage of children in severe poverty, life satisfaction, etc.) and measures of quality of government/state capacity are high and significant, the correlations with a measure of the level of democracy is either null or very small (Holmberg and Rothstein, 2014; Rothstein and Holmberg, 2014). As shown by 
Amartya Sen, we have to face the fact that autocratic communist China now outperforms liberal democratic India on every standard measure of human well-being (Sen, 2011). There is much suggesting that this can be explained by the way the Chinese have managed to organize their public administration for simultaneously securing competence and ideological coherence (Rothstein, 2015a; Ahlers and Schubert, 2011). As argued by Fukuyama, in development research, almost all political scientists have focused on what explains democratization and very few have paid any attention to issues about how to build state capacity - that is, how to secure a reasonably competent, incorrupt and impartial public administration (Fukuyama, 2014b; Rothstein and Tannenberg, 2015). The latter seems in fact much more difficult to accomplish than organizing democratic elections. In Afghanistan and Iraq, the U.S. managed to establish reasonably legitimate elections after the invasions but failed completely in building (or re-building) state capacity, and there is much that suggests that the lack of development as well as the terrorism coming out of these countries today is due to this failure (Fukuyama, 2014a). Moreover, Norris (2015) has shown that one requirement for establishing integrity in elections is a competent, professional, unbiased administration that can be entrusted with this complicated administrative task. One could say that excluding public administration from understanding how the political system operates is to cut off from the discipline these areas where most of the important action for establishing political legitimacy and delivering human wellbeing takes place. And, if we believe that research that has implications for political legitimacy and human well-being is also of high relevance, the separation of public administration issues from the discipline must be a problem. ${ }^{1}$ It is probably not a coincidence that the current 'primus inter pares' among Nordic political scientists - Johan P. Olsen at the University of Oslo - is by and large a public administration scholar and also a researcher who has had a huge policy influence in the Nordic countries, not least as a leading member of two of the four mega-research projects carried out during the last three decades known as the 'power and democracy' investigations (Elmgren and Götz, 2013). Leading political scientists and political philosophers in Europe also publish books about how to increase the policy impact from our discipline (Bastow, Dunleavy, and Tinkler, 2014; Wolff, 2011).

\section{Iron Wall II. The Isolation of Political Theory in American Political Science}

\footnotetext{
${ }^{1}$ In all likelihood, this division has also been detrimental for Public Administration research in the U.S. but that is for another essay.
} 
It is my impression that the field of political theory is more separated and isolated from empirical political science in the U.S. than in Europe and definitively so in the Nordic countries. While harbouring in the same formal departments, political theorists seldom interact with empirical researchers in, for example, comparative politics. This isolation is also institutionalized in the way sections and panels are constructed at the major American conferences. I must have been to more than two hundred such conference panels over the years but I cannot remember a single discussion taking part between a political theorist and a comparative political scientist. Since my fields were welfare state and social policies, social capital and lately corruption and the quality of government, I have always found this division very strange and have tried to surpass it in my own writing (Rothstein, 1998; 2005). For example, social and welfare policy concern normative issues about social justice and what our obligations are to less fortunate citizens. In a way, much of what political theory, from Aristotle to Rawls, is about concerns a quite simple question, namely what ought the state to do? Or framed differently, what is our own responsibility as citizens and what should we have the right to claim as support from the collective? Empirical research concerns very much what the state can do in these areas. What type of policies can gain popular support, which type of policies can be implemented without causing bureaucratic nightmare or damage to the economy? Obviously, none of these questions can, or should, be answered separately if one wants to be relevant to the public debate or public policy. Arguing that the state ought to do something that empirical research shows it cannot do, or showing that the state can do something that, from an ethical perspective, it should not do, will not give you any leverage when it comes to relevance. But this is how much of political theory and empirical research about the welfare state and social policy has been conducted in American political science. As I have argued elsewhere, both political theory and empirical research are being handicapped by the institutionalization of this 'iron wall' (Rothstein, 2015b). Political theorists, for example, can propose policies for increased social justice that from empirical research are known to lead to such bureaucratic nightmares that the result would be the creation of a political majority against policies for increased social justice.

The same problem impedes research about corruption. The lack of a clear, normative foundation of the concept of corruption has seriously hurt the relevance of this research. For example, the standard definition of corruption in empirical research is some variant 'abuse of public power for private gain'. This is a normatively empty and technocratic definition because what should count as 'abuse' is not defined. As a result, this has invited all sorts of 
cultural relativism in this area of study because what is counted as 'abuse' in Denmark differs from what this is in Nigeria. This difference turns out empirically not to be the case but the damage is already done because the norm that is transgressed when we can talk about abuse of a position of public power is not specified (Rothstein, 2014). It is like stating that gender equality is also respected in Saudi Arabia, they just happen to have a somewhat different idea of what this is. In sum, it is my impression that empirical political scientists in the U.S. are more afraid of being seen as 'normative', compared to their European colleagues. It is probably not a coincidence that it is political theorists working in Europe, for example; Brian Barry, Robert Goodin, Cathrine Holst and David Miller that have succeeded in combining political philosophy with insights and results from empirical research. My impression is that too many political theorists in the U.S. are content with a role more like museum curators polishing their favourite ancient political philosopher.

\section{The Institutionalization of Intellectual Exchange}

There may be many reasons for the differences between how political science works in the U.S. and in Europe. One potential explanation could be how the main conferences are organized. As is well known, the Annual Meeting of the American Political Science as well as the regional conferences are dominated by short (about 90 minutes) panels in which four or five paper givers and one or two discussants have to share the time. Usually, the panels are organized by scholars who think alike and have a very common approach and the ambition is not so much intellectual discussion but instead to market their common approach. Very little time is given to each paper, and in many cases there is no time for questions from the audience. This way of organizing intellectual exchange does not promote discussions between people from different parts of the discipline, instead what is promoted is 'group think' and a market-based approach to intellectual work. The main political science conference in Europe has been the 'Joint Session of Workshops' that has been organized by the European Consortium for Political Research every year since 1973. At these conferences, the operative logic is very different from the American style. The workshops are organized around themes, which are often problem and policy oriented, thus promoting relevance in the abovementioned sense. The workshops consist of about fifteen to twenty participants and they last for four whole days implying that each paper is given about an hour. This mode of organizing intellectual exchange was set-up by leading European scholars such as Hans Daalder and 
Stein Rokkan, as a reaction to the American short panel style that they found too superficial. The workshop style invites longer and more thorough discussions of each contribution and this can, in my experience, work to break down barriers between different approaches.

Scholars with different methodological and theoretical approaches are together for a week to discuss research around a specific theme and this makes it more difficult to establish the type or "iron walls" mentioned above.

\section{Summary}

Are there differences when it comes to relevance between American and European political science? My tentative answer is yes, and one of my arguments is the failure of our American colleagues to fend of the attack launched from the U.S. Congress on funding for political science research. There can, of course, be a myriad of explanations for this, for example historical legacies, the role of the OECD in Europe and the demand for the European Union's different research funding operations for dissemination of research results. However, in this essay I have pointed at four possible internal institutional differences, namely what I called the 'drain to law school' of students who are interested in having policy influence and the two iron walls to public administration and political theory which according to my impressions are more profound and difficult to climb over in the U.S. than is the case in the European part of the discipline. In addition, I have pointed to the differences in how the main conferences in the discipline are organized. Admittedly my reasoning is, for the most part, built on personal impressions and can only serve as a starting point for future analyses and discussions.

\section{References}

Ahlers, Anna L, and Gunter Schubert. 2011. "“Adaptive Authoritarianism” in Contemporary China: Identifying Zones of Legitimacy Building." In Reviving Legitimacy: Lessons for and from China, edited by Deng Zhenglai and Sujian Guo, 61-82. Lanham: Lexington Books.

Bastow, Simon, Patrick Dunleavy, and Jane Tinkler. 2014. The Impact of the Social Sciences: How Academics and their Research Make a Difference. London: Sage.

Elmgren, Ainur, and Norbert Götz. 2013. "Power Investigation: The Political Culture of Nordic SelfUnderstanding. Special Issue." Journal of Contemporary European Studies no. 21 (3).

Gilley, Bruce. 2009. The Right to Rule: How states win and lose legitimacy. New York: Columbia University Press.

Gjefsen, Torbjorn. 2012. Sources of Legitimacy: Quality of Government and Electoral Democracy (MA Thesis). Department of Political Science, University of Oslo, Oslo. 
Fukuyama, Francis. 2014a. Political order and political decay : from the industrial revolution to the globalization of democracy. First ed. New York: Farrar, Straus \& Giroux.

Fukuyama, Francis. 2014b. "States and Democracy." Democratization no. 21 (7):1326-1340.

Dahlberg, Stefan, and Sören Holmberg. 2014. "Democracy and Bureaucracy: How their Quality Matters for Popular Satisfaction." West European Politics 37 (3):515-7.

Holmberg, Sören, and Bo Rothstein. 2014. Correlates of The Level of Democracy. Gothenburg: The Quality of Government Institute, University of Gothenburg. QoG Working Paper 2014:18.

Holmberg, Sören, and Bo. Rothstein, eds. 2012. Good Government: The Relevance of Political Science. Cheltenham: Edward Elgar.

Kristof, Nicholas. 2014. "Professors, We Need You!" The New York Times, 15 Febr. 2014.

Linde, Jonas, and Stefan Dahlberg. 2016. Democratic Legitimacy \& Quality of Government: A Comparative Anslysis. Cheltenham: Edward Elgar (forthcoming).

Norris, Pippa. 2015. Why Elections Fail. Cambridge: Cambridge University Press.

Pierre, Jon, ed. 2015. The Oxford Handbook of Swedish Politics. Oxford: Oxford University Press.

Rothstein, Bo. 1998. Just Institutions Matter: The Moral and Political Logic of the Universal Welfare State. Cambridge: Cambridge University Press.

Rothstein, Bo. 2005. Social Traps and the Problem of Trust. Cambridge: Cambridge University Press.

Rothstein, Bo. 2011. The Quality of Government: Corruption, Social Trust and Inequality in a Comparative Perspective. Chicago: The University of Chicago Press.

Rothstein, Bo. 2014. "What is the opposite of corruption?" Third World Quarterly no. 35 (5):737-757.

Rothstein, Bo. 2015a. "The Chinese Paradox of High Growth and Low Quality of Government: The Cadre Organization Meets Max Weber." Governance: An International Journal of Policy, Administration and Institutions no. 28 (4):533-548.

Rothstein, Bo. 2015b. "Gulty as Charged? Human Well-Being and the Unsung Relevance of Political Science." In The Relevance of Political Science, edited by Gerry Stoker, B. Guy Peters and Jon Pierre, 101-123. New York: Palgrave.

Rothstein, Bo, and Sören Holmberg. 2014. Correlates of Corruption. Gothenburg: The Quality of Government Institute, University of Gothenburg. QoG Working Paper 2014:17.

Rothstein, Bo, and Marcus Tannenberg. 2015. Making Development Work: The Quality of Government Approach. Stockholm: Swedish Government Expert Group for Aid Studies.

Sen, Amartya. 2011. "Quality of Life: India vs. China." New York Review of Books no. LVIII (2011:25):44-47.

Skocpol, Theda. 1992. Protecting Soldiers and Mothers: The Political Origins of Social Policy in the United States. Cambridge, Mass.: Harvard University Press.

Stoker, Gerry, B. Guy Peters, and Jon Pierre, eds. 2015. The Relevance of Political Science. New York: Palgrave Macmillan.

Svallfors, Stefan. 2013. "Government quality, egalitarianism, and attitudes to taxes and social spending: a European comparison." European Political Science Review 5 (3):363-380.

Wolff, Jonathan. 2011. Ethics and Public Policy: A philosophical inquiry. Milton Park, Abingdon, Oxon; New York: Routledge. 